\title{
Tajun ja tajuttomuuden välissä
}

Sihvonen Jukka (2004). Mediatajun paluu - pistokkeen päässä. LIKE . 185 sivua.

Elokuvatutkimuksen professori Jukka Sihvosen teos Mediatajun paluu ei pyri antamaan konkreettisia työkaluja, joilla mediakasvatusta voitaisiin opettaa. Sen sijaan hän ottaa askeleen taaksepäin ja lähtee tutkimaan niitä lähtökohtia, joiden avulla mediakasvatusta voidaan ylipäätään alkaa ajatella. Käytännössä nämä voidaan kiteyttää kahteen laajempaan ongelmakenttään. Ensinnäkin siihen miten jatkuvassa muutoksessa olevaan mediaan voidaan tarttua ja toiseksi millaisena ilmiönä ihmisen ja median välinen suhde tulisi käsittää?

Mediatajun paluu on työstetty Sihvosen aiemmista esseistä ja se haarukoi aihepiiriään laaja-alaisesti vaikka eksplisiittisempää otetta tiettyihin kysymyksiin jääkin kaipaamaan. Toisaalta tällainen rakenne noudattaa hyvin kirjan esittämää pedagogiikkaa: kyse ei ole valmiiden ajatusten antamisesta vaan pyrkimyksestä herättää inmisessä oleva potentiaali ajatella. Tämä voitaisiin nähdä myös jonkinlaisena mediakasvatuksen päämääränä.

Sihvosen oivallus on, että mediaa ei tulisi määritellä sen välineiden tai teknologioiden mukaan vaan pitäisi etsiä erilaisten mediumien taustalla olevia laajempia yhdistäviä kulttuurisia ilmiöitä. Tietyllä tavalla kyse on jo Kantilta peräisin olevasta näkemyksestä, jossa asiaan itsessään ei ole pääsyä, mutta on olemassa tiettyjä ana- lysoitavia rakenteita, joiden avulla asioita hahmotamme. Sihvoselle pysäytyskuvan- ja valvontakameran -käsitteet edustavat tällaisia rakenteita, sillä ne ovat "kaksi teknologista, ideologista ja ilmaisullista muotoa", jotka "määrittävät mediatajun ajallis-tilalliset ulottuvuudet" (s. 14).

Pysäytyskuvassa on kyse pyrkimyksestä kontrolloida ja jäsentää aikaa pysäyttämällä sen virta. "'Koko maailman' pysäyttivät WTC:n torneihin pysähtyneet matkustajalentokoneet nelisen vuotta Dianan pysähtymisen jälkeen ja 'koko Suomi' taas pysähtyi Myyrmannin räjähdyksen hetkellä lokakuussa 2002" (s. 59-60). Valvontakamera taas on metafora todellisuuden ilmaisulliselle voimalle. Kyse on esimerkiksi "bittipelien" tavasta tuottaa jatkuvuudeltaan mahdollisimman aidoilta vaikuttavia ympäristöjä. Tiivistetysti sekä pysäytyskuvassa että valvontakamerassa on kyse uudenlaisesta ajan ja tilan hahmottamisen logiikasta.

Teoksessaan Sihvonen pyrkii ravistelemaan kahta perinteistä käsitystä, jotka koskevat suhtautumista mediaan ja mediakasvatukseen. Yhtäällä on esimerkiksi Neil Postmanin 1980luvulla muotoilema ajatus "augustinolaisesta selibaatista"käsityksestä, jonka mukaan media nähdään lapsuuden tuhoavana isona pahana sutena. Toista ääripäätä edustaa koulukunta, jolle media näyttäytyy messiaanisena yltäkylläisyyden ja kaikkivoipaisuuden voimana, joka vapauttaa lapset toteuttamaan itseään. Sihvosen mukaan kumpikin kyseisistä ajattelumalleista sortuu yksiulotteiseen ja idealisoivaan käsitykseen sekä mediasta että lapsuudesta. "Ensimmäinen askel kohti kokonaisvaltaisempaa mediatajua on oivaltaa, että kasvun mahdollisuudet eivät rajoitu näihin kahteen vaihtoehtoon", Sihvonen toteaa (s. 176).

Mediataju sijaitsee siis jossain turruttavan tajuttomuuden lähteen ja toisaalta uudenlaisten potentiaalien välimaastossa. Sihvosen pohja mediatajuiselle inmiselle löytyy Giorgio Agambenin homo sacer -ihmisen käsitteestä: "Agambenille homo sacer on erilaisia inmismäisinä ja ei-ihmismäisinä ymmärrettyjä välitiloja merkitsevä 'kynnystermi”' (s. 176). Sihvosen ajattelussa inminen määrittyy tällöin hahmoksi, jossa inhimillinen (lapsuus) ja ei-inhimillinen (media) kohtaavat. Kyse ei enää ole dikotomisesta suhteesta, jossa inminen ja media voidaan erottaa toisistaan vaan Sihvosen mukaan saatamme olla siirtymässä aikakauteen, jolloin elämänmuotoja median määrittämien rajojen ulkopuolella ei enää ole.

Sihvosen näkemys tällaisesta elämästä ei kuitenkaan ole pessimistinen, vaan se tulisi mieluummin mieltää olemassa olevana tosiasiana, johon on vain opittava suhtautumaan. Mediataju voi palata mediatajuttomuudesta, mikäli "mediaiskujen" rakennetekijät opitaan tuntemaan syvällisemmin (s.178-179). Tätä voisi olla mediakasvatus. 